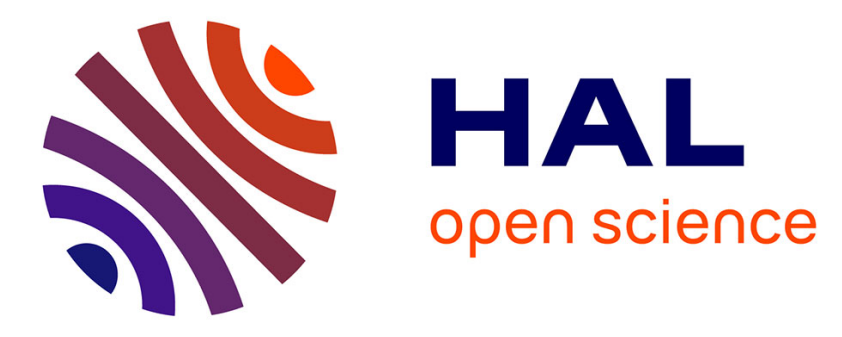

\title{
Geophysical investigation of a large landslide in glaciolacustrine clays in the Trièves area (French Alps)
}

Denis Jongmans, Grégory Bièvre, Florence Renalier, Stéphane Schwartz, Nicolas Beaurez, Yves Orengo

\section{To cite this version:}

Denis Jongmans, Grégory Bièvre, Florence Renalier, Stéphane Schwartz, Nicolas Beaurez, et al.. Geophysical investigation of a large landslide in glaciolacustrine clays in the Trièves area (French Alps). Engineering Geology, 2009, 109 (1-2), pp.45-56. 10.1016/j.enggeo.2008.10.005 . insu-00522819

\section{HAL Id: insu-00522819 https://hal-insu.archives-ouvertes.fr/insu-00522819}

Submitted on 1 Oct 2010

HAL is a multi-disciplinary open access archive for the deposit and dissemination of scientific research documents, whether they are published or not. The documents may come from teaching and research institutions in France or abroad, or from public or private research centers.
L'archive ouverte pluridisciplinaire $\mathbf{H A L}$, est destinée au dépôt et à la diffusion de documents scientifiques de niveau recherche, publiés ou non, émanant des établissements d'enseignement et de recherche français ou étrangers, des laboratoires publics ou privés. 


\title{
Geophysical investigation of a large landslide in glaciolacustrine clays in the Trièves area (French Alps)
}

\author{
Jongmans D. ${ }^{1}$, Bièvre G. ${ }^{1,2}$, Renalier F. ${ }^{1}$, Schwartz S. ${ }^{1}$, Beaurez N. ${ }^{2}$ and Orengo Y. ${ }^{1}$ \\ ${ }^{1}$ LGIT, Maison des Géosciences, Université Joseph Fourier, BP 53, 38041 Grenoble Cedex 9, France. \\ ${ }^{2}$ CETE Lyon, LRPC Autun, BP 141, 71404 Autun cedex, France
}

\begin{abstract}
Slope movements in clay deposits are world widespread and result from complex deformation processes, including internal strains in the landslide body and slipping along rupture surfaces. Such mass movements are likely to generate changes in the geophysical parameters characterizing the ground, which can be used to map the landslide body. In the last decade, geophysical techniques have been increasingly used for landslide investigation purposes. However, the success of any geophysical technique is overall controlled by the existence of a geophysical contrast differentiating the body to be mapped. For landslides affecting thick clay materials (from soft clay to shale or marl), electrical and seismic techniques have been mainly applied in the past. In this study, we attempt to physically characterize the deformation within a large slide (Avignonet) affecting laminated clays which were deposited in a glacially dammed lake during the Würm period. Clay deposits, which cover an area of $300 \mathrm{~km}^{2}$ south of Grenoble (French Alps) and have a maximum thickness of $200 \mathrm{~m}$, overlay compact alluvial layers and marly limestone of Mesozoic age. Piezometric data at Avignonet show that the water table is very shallow, implying that the slide developed in saturated clay. Several seismic and electrical profiles were performed in order to tentatively correlate the variations of P-wave velocity, S-wave velocity and electrical resistivity with geotechnical data and morphological observations. In such saturated and fine material, it turned out that only the S-wave velocity (Vs) exhibits significant variations with the displacement rates and the morphological features. Vs values at shallow depth were found to be inversely correlated with displacement rates measured by GPS, with a division by at least a factor of 2 between the zones unaffected and strongly deformed by the landslide. These results suggest that Vs mapping could provide valuable information on the deformation state of the clay material and that the evolution of Vs with time could be used as an indicator for characterizing the landslide activity at depth, including the evolution into a flow.
\end{abstract}

\section{Introduction}

The Trièves area (French Alps) is covered by Quaternary clays with a maximum thickness of $200 \mathrm{~m}$, which were deposited in a glacially dammed lake during the Würm period (Monjuvent, 1973). These clay deposits are affected by numerous deep landslides which can evolve into mudflows. Slope movements in such fine grained soils are world widespread and usually result from complex deformation processes, including internal strains in the landslide body and slipping along rupture surfaces (see Picarelli, 2000 and Picarelli et al., 2004). Such mass movements are likely to generate changes in the geophysical parameters characterizing the ground, which can be used to map the landslide body. Since the pioneering work of Bogoslovsky and Ogilvy (1977), geophysical techniques have been increasingly but relatively little used (or referenced) for landslide investigation purposes. A review of the application of geophysical techniques to landslide investigation was recently published (Jongmans and Garambois, 2007). Among the reasons explaining the reluctance to employ geophysical 
techniques, one can mention the relative difficulty of deploying geophysical layouts (although the expense is far less than the one required for drilling), the limitations of most ancient geophysical methods to adequately investigate a 3D structure, and the problem of linking the measured geophysical parameters to geotechnical properties. Over the last fifty years, since the pioneering works of Archie (1942) and Willye et al. (1956) an enormous effort has been made in petroleum exploration to understand, both theoretically and experimentally, the relations between geophysical parameters (seismic, electrical and dielectric) and rock mass properties (for a review, see for instance Mavko et al., 2003). In clay material specifically, Mondol et al. (2007) recently studied the changes in geophysical properties during burial through experimental tests on dry and brine saturated clay aggregates from smectite to kaolinite. In saturated samples, Vp values were shown to be sensitive to the vertical effective stress, increasing on average from $1500 \mathrm{~m} / \mathrm{s}$ at $5 \mathrm{MPa}$ to $2350 \mathrm{~m} / \mathrm{s}$ at $50 \mathrm{Mpa}$. Vs values exhibit the same tendency but with a far greater variation, from $300 \mathrm{~m} / \mathrm{s}$ to almost $850 \mathrm{~m} / \mathrm{s}$ for the same stress values. At shallow depth, Leucci and Giorgi (2006) investigated the effects of fracture on $\mathrm{P}$ and $\mathrm{S}$ wave velocity values in sedimentary rocks. They experimentally showed that, if the two seismic velocities significantly decrease with the fracturing intensity, Vs is more sensitive to fracture parameters. These two studies, among many others, illustrate that geophysical parameters can be of interest for characterizing ground mechanical properties like the compactness or the degree of fracturing.

The recent emergence of 2D and 3D geophysical imaging techniques, easy to deploy on slopes and investigating a large volume in a non-invasive way, has made more attractive the geophysical techniques for landslide applications. However, the success of any geophysical campaign depends on four main controlling factors (McCann and Forster, 1990): the existence of a geophysical contrast differentiating the body to be mapped, the resolution and penetration of the method, the calibration of geophysical techniques by geological or geotechnical data and, finally, the signal to noise ratio. In the case of landslides affecting thick clayey deposits (from soft clay to shale or marl), the geophysical techniques mostly used in the past were the electrical methods (Caris and van Asch, 1991; Schmutz et al., 2000; Lapenna et al., 2005; Méric et al., 2007) and the seismic methods (Caris and van Asch, 1991; Grandjean et al., 2006; Méric et al., 2007). In compact clays and marls, the landslide body was found to be associated with low resistivity values (generally between 10 and $30 \Omega . \mathrm{m}$ ) while the unaffected ground is characterized by a resistivity over $60-75 \Omega . \mathrm{m}$. (Caris and van Asch, 1991; Schmutz et al., 2000; Lapenna et al., 2005). The dislocation of this material by the slide allows the weathering of the minerals and the water content to be increased, lowering the resistivity values in the landslide body. As the motion and the resulting internal strains can alter the compacity of the moving mass, seismic methods usually show a contrast in seismic velocity (P-wave or S-wave) between the slide and the unaffected ground. Applying the seismic refraction technique on a small landslide in black marl material (French Alps), Caris and Van Asch (1991) found a strong P-wave velocity contrast between the landslide body $(350 \mathrm{~m} / \mathrm{s})$ and the bedrock $(2800 \mathrm{~m} / \mathrm{s})$ which varies in depth between 4 and $9 \mathrm{~m}$. Méric et al. (2007) derived S-wave velocity profiles on two landslides in clayey materials, from the inversion of surface waves (Wathelet et al., 2004). In both cases, a large contrast of Vs was detected between the sliding $(250-300 \mathrm{~m} / \mathrm{s})$ and the stable mass $(550-800 \mathrm{~m} / \mathrm{s})$ at depths varying between 20 and $35 \mathrm{~m}$, in agreement with other geophysical data and borehole measurements. The H/V technique (Nakamura, 1989), which measures the fundamental frequency of the site, was applied on clayey landslides (Gallipoli et al., 2000, Méric et al., 2007) for estimating the depth of the rupture surface assuming a constant Vs value within the slide. This quick and easy to interpret technique can however yield inaccurate results in case of severe 2D and 3D effects (Guillier et al., 2006). 
This review shows that three geophysical parameters (electrical resistivity, P-wave velocity and S-wave velocity) were used for distinguishing and characterizing the sliding mass in various clayey deposits. The aim of this study is to test the ability of these three geophysical parameters to characterize the deformation generated by the Avignonet landslide affecting saturated laminated clays. Five different geophysical methods (seismic noise measurement, electrical tomography, P-wave seismic refraction, S-wave seismic refraction and surface wave inversion) were applied along a profile where geotechnical data (borehole logs, inclinometer data, GPS measurements) are available. Confrontation between the two sets of data allowed sorting out the S-wave velocity as the more sensitive parameter to gravitational deformation in such kind of deposits.

\section{Geological and geotechnical contexts}

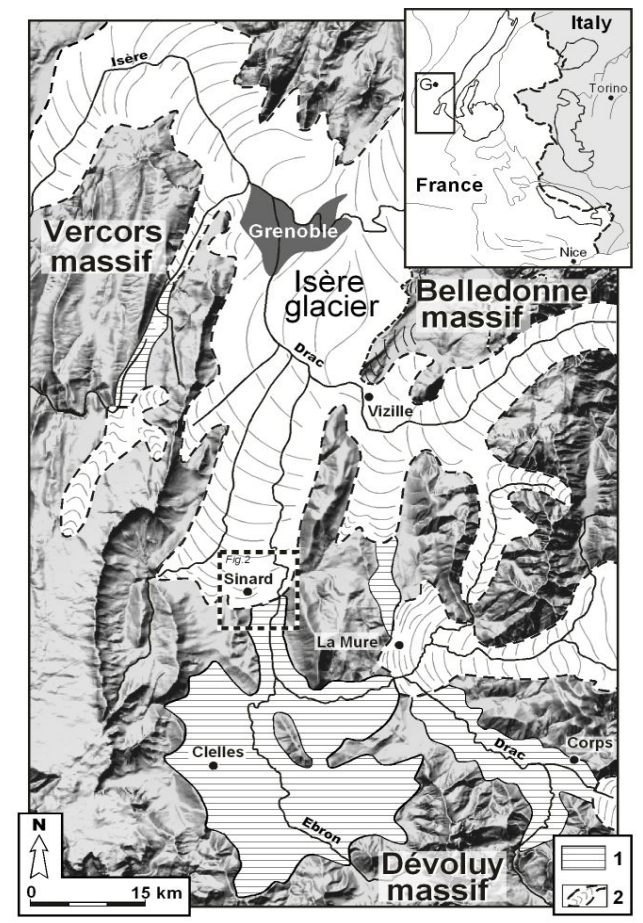

Figure 1: Location map of Grenoble and the Trièves region. 1: Clay deposits in the Trièves region. 2: Extension of the glaciers at the end of the Würm period. The studied area is indicated with a box (dashed bold line).

The Trièves region is located 40 kilometres south of the city of Grenoble in the western Alps (Figure 1). Morphologically, this area is a large depression of about $300 \mathrm{~km}^{2}$, which is drained by the Drac River and its tributaries. It is limited to the West and the South by the Vercors and the Dévoluy carbonate massifs, respectively, and to the East, by the dome structure of La Mure (Figure 1). During the last maximum glacial extension (Würm period, $45000 \mathrm{yr}$ ), the Isère glacier blocked downstream the torrential flows coming from the South (Figure 1) generating an ice-dammed lake (Monjuvent, 1973). This lake progressively invaded the whole zone during several thousands of years and was filled by varved clays, coming mainly from the erosion of the Vercors and Dévoluy piedmonts. The clay deposits rest on either the glaciofluvial materials (gravels and sands) of the interglacial Riss-Würm period or on the underlying Jurassic carbonate bedrock which was folded and faulted during the alpine orogenesis. The thickness of the clay deposits can then vary dramatically over a short distance, from 0 to a maximum of $250 \mathrm{~m}$ (Antoine et al., 1981), the clay top reaching 
maximum altitude of $750 \mathrm{~m}$. After the sedimentation, the varved clays were partly covered by the morainic terminal deposits brought by the rising of the Isère glacier at the end of the Würm period. This geological history explains the relatively flat depression of the Trièves region with clay outcropping over a large surface. After the glacier melting the rivers cut deeply into the geological formations and at least $15 \%$ of the area covered by the clay deposits is now considered as sliding. Some of these slides might affect surfaces as large as $500000 \mathrm{~m}^{2}$ with the deepest surface of rupture estimated or measured at $40 \mathrm{~m}$ depth. The climate of the region is submediterranean with alpine influences and the activity of the landslides is generally seasonal with the largest displacement rates measured after snow melt and rain fall (Giraud et al., 1991; van Asch et al., 1996). Most of these slides are moving slowly at a rate of a few $\mathrm{cm} /$ year or less (with local values as high as $1 \mathrm{~m} /$ year) but in several catastrophic cases these slides evolved into a mudflow with dramatic accelerations (Moulin and Robert, 2004). The geological and geotechnical properties of the glaciolacustrine clays outcropping in the Trièves area were intensively studied in the eighties and synthesized after more than 10 years of observations and monitoring of several landslides (Giraud et al., 1991; Blanchet, 1988). Just the main characteristics are reminded here. These clays are finely laminated with light coloured silty beds alternating with dark coloured clayey beds. From grain size analysis, they are classified as clayey silts. The bed thickness varies between $1 \mathrm{~mm}$ to $10 \mathrm{~cm}$. In the Sinard sector, the main minerals are illite (42-47\%), calcite (15-20\%), quartz (14-16\%), chlorite (14-16\%) and feldspar (5-10\%). The dry density is about $15-16 \mathrm{kN} / \mathrm{m}^{3}$ with the natural water content varying between $23 \%$ and $31 \%$. The liquid limit was measured between $30 \%$ and $48 \%$. The plasticity index Ip is relatively low (between $10 \%$ and $25 \%$ ), which means that the liquid limit can be quickly reached, particularly near the surface, explaining the numerous observed solifluction flows. Oedemeter tests on samples taken at a depth of 3-4 m yielded high overconsolidation ratios (OCR), between 13 and 20, probably resulting from the effect of the glaciers. Consolidated drained direct shear tests provided residual values of practically zero for the cohesion and of $18-19^{\circ}$ for the friction angle. Permeability was estimated at about $10^{-10} \mathrm{~m} / \mathrm{s}$ perpendicular to the bedding and at $10^{-8} \mathrm{~m} / \mathrm{s}$ parallel to the bedding, resulting from the textural anisotropy.

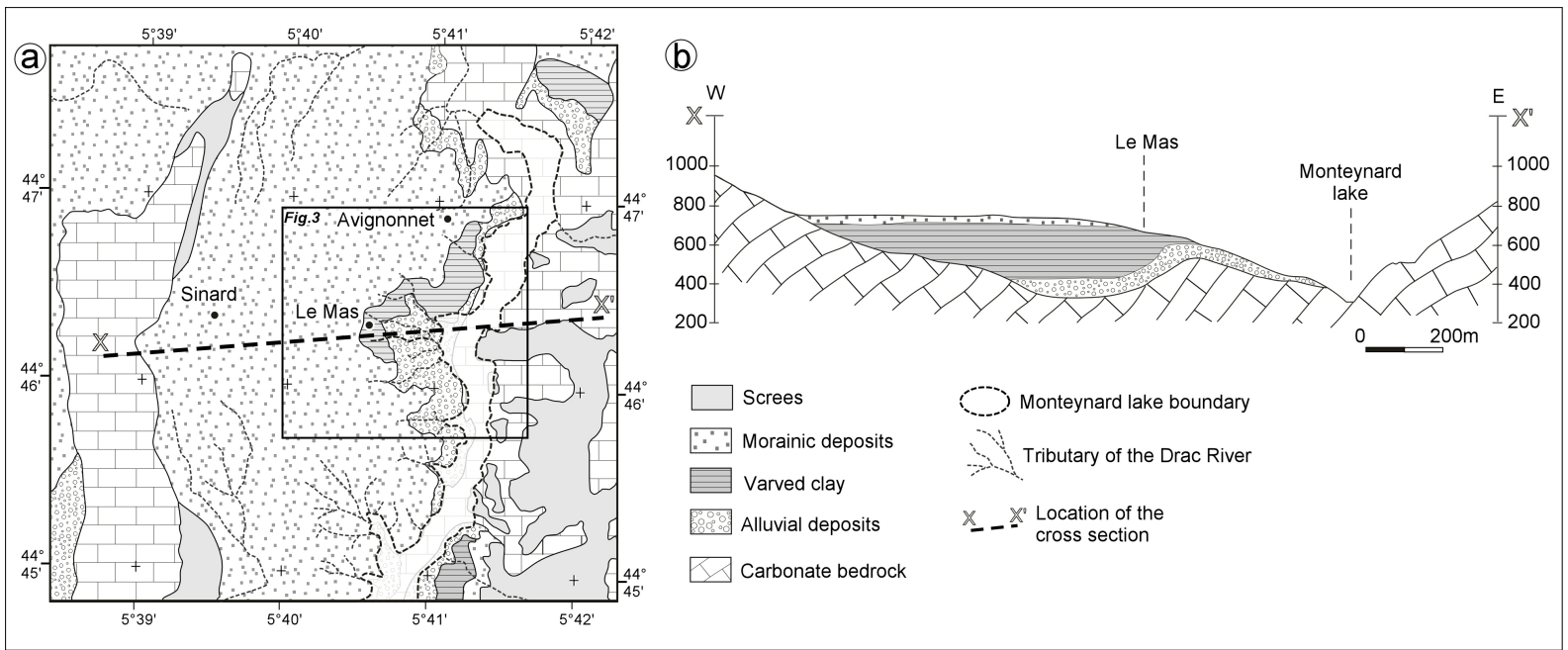

Figure 2: a) Geological map and b) cross-section (XX') showing the structure of the region. The Avignonet landslide is within the rectangle.

The Avignonet landslide is located east of the village of Sinard, along the Monteynard Lake (Figure 2). In this area, the thickness of the clay deposits varies from 0 to $200 \mathrm{~m}$ thick (Figure $2 b$ ). They overlay either compact old alluvial deposits of the Drac river and/or marly 
limestone of Lias age. The alluvial deposits are made of a succession of cemented sand, gravel and pebble layers, overlaid with a level of blocky clay (Blanchet, 1988). The rocks outcrop on the eastern side of the lake and also make a N-S orientated hill to the west (Figure $2 a$ ). The clays are covered by a thin layer (a few meters thick) of moraine material which on the slopes are mixed up with displaced laminated clays, constituting a more permeable colluvial layer. The Avignonet slide affects a surface of about $1.10^{6} \mathrm{~m}^{2}$ (Figure 3). The head scarp, which is approximately located at an elevation of $800 \mathrm{~m}$, corresponds to the eastern border of the plateau (Figures 2 and 3). Within the slide, the slope angle is between $8^{\circ}$ and $15^{\circ}$ and numerous signs of instability are found like scarps, fissures, gullies and mudflows (Figure 3 ). Below the slide toe, the slope angle increases to $20^{\circ}$ in the alluvial layers underlying the clay deposits.
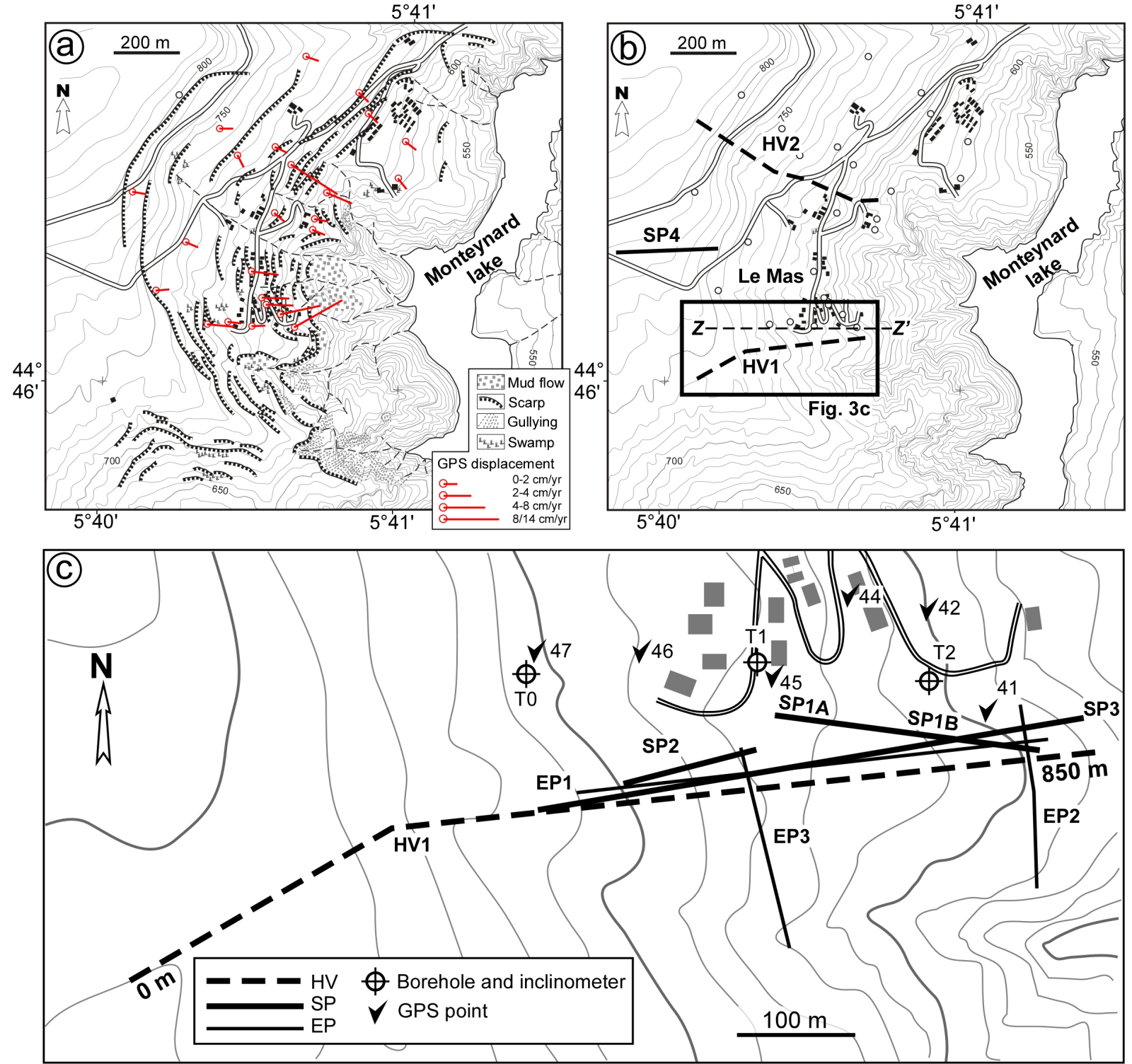

Figure 3: a) Map of the Avignonet landslide with the location of the scarps and the displacement rates. b) The same with the location of the long geophysical profiles. The zone investigated in detail is indicated with a rectangle. Location of cross-section $Z Z$ ' is indicated. c) Map of the investigated zone with the location of the geophysical experiments, boreholes, inclinometers and GPS points. Direction and length of HV1 profile is indicated. 
The first signs of instability were noticed between 1976 and 1981, during housing development (Lorier and Desvarreux, 2004). Geotechnical investigation showed the existence of several slip surfaces, from very superficial ones (a few $\mathrm{m}$ ) to deep ruptures at $40 \mathrm{~m}$ (Lorier and Desvarreux, 2004; Figure 1). The slide velocity at the surface, measured by GPS during more than 10 years, increases downhill, varying from 0 to $2 \mathrm{~cm} / \mathrm{y}$ at the top to more than 14 $\mathrm{cm} / \mathrm{y}$ at the toe (Figure 3a). These geodetic data are consistent with geomorphic observations (scarps, fissures, swampy areas, bulges), which show an increase of the landslide activity downstream. Piezometric data have pointed out a shallow water table (a few $\mathrm{m}$ to $1 \mathrm{~m}$ deep) which fluctuates with rainfalls. If some data show a relation between water level and displacement rate, the highest slide velocity values do not seem to depend on rainfalls (Lorier and Desvarreux, 2004). In case of heavy rainfalls or quick snow melt, this kind of slide might evolve into a mudflow, as shown by the events of L'Harmalière (1981) (Moulin and Robert, 2004) and of La Salle en Beaumont (1994) (Moulin and Chapeau, 2004), as well as by numerous solifluction flows.
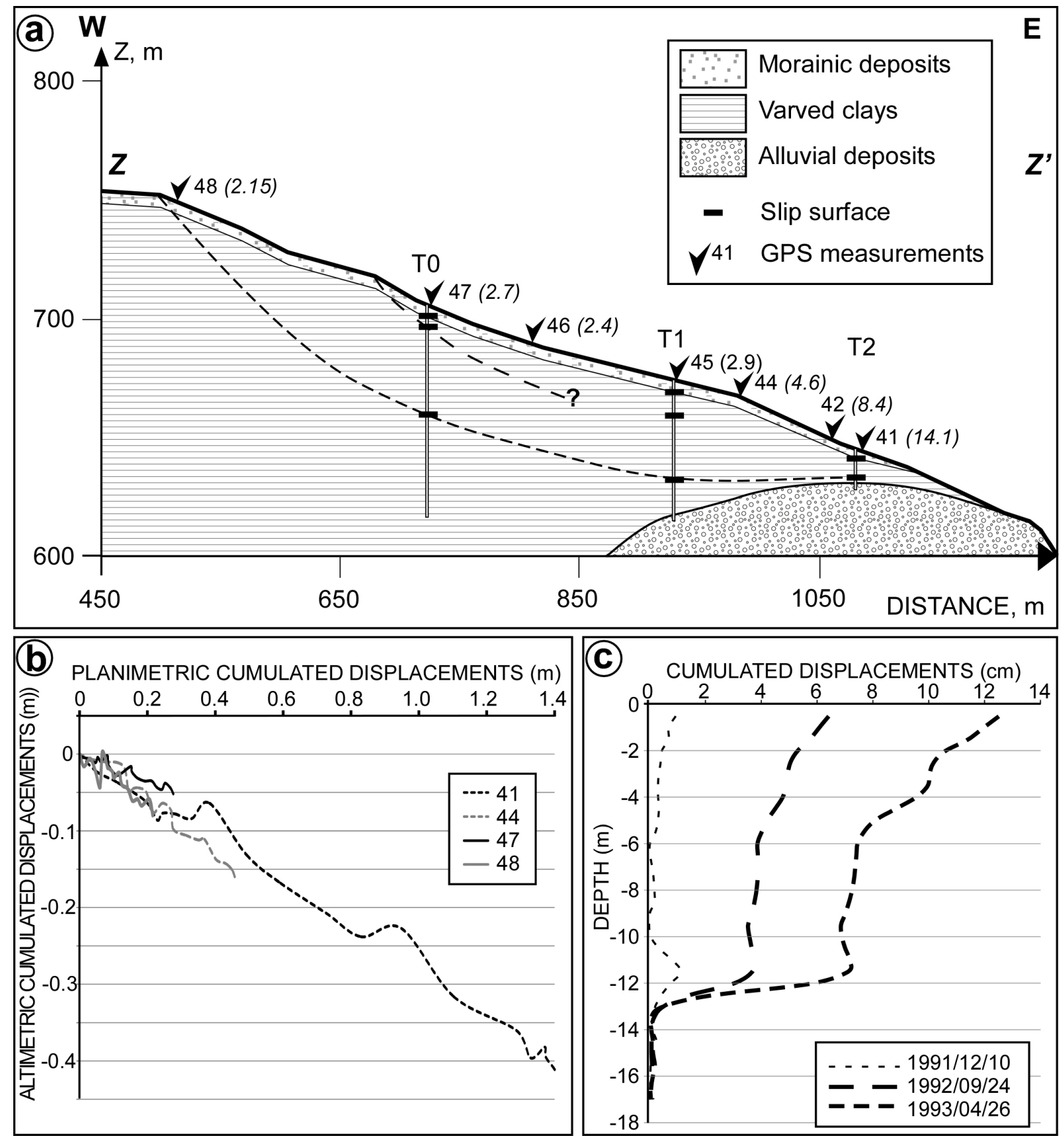
Figure 4: a) Geotechnical cross section ZZ' (location in Fig. 3b) with the position of GPS points (displacement rate in $\mathrm{cm} / y r$ indicated between parentheses) and the slip planes deduced from inclinometer data. The vertical scale is exaggerated. b) Displacements in the horizontal and vertical planes at GPS points 41, 44, 47 and 48 (between 1995/10/01 and 2005/10/26). c) Cumulated displacements curve at inclinometer T2; reference curve was measured on 1990/04/10.

A specific zone of the landslide was studied along the hamlet of Le Mas (Figure 3) where geotechnical investigation was concentrated with three boreholes (T0 to T2) equipped with inclinometers, and with six GPS points. The main geotechnical information is summarized on the cross section ZZ' (Figure 4) located in Figure 3b. Boreholes T2 and T1 found the stiff alluvial layer at a depth of $14.5 \mathrm{~m}$ and $44.5 \mathrm{~m}$, respectively, while T0 was stopped in the clay at $89 \mathrm{~m}$, in agreement with the westward thickening of the clay deposit shown in Figure 2a. Slip surfaces were detected in the three boreholes (Figure 4a) at depths varying between a few $\mathrm{m}$ to $48 \mathrm{~m}$. Figure $4 \mathrm{c}$ shows the inclinometer data measured over 1.5 years in borehole T2 where the most active rupture surface is located at $13 \mathrm{~m}$, over the clay-alluvium boundary. In T0 and T1, the maximum displacements were found at 4 and $48 \mathrm{~m}$, respectively. Displacement rates at the surface strongly increase downhill, from $2 \mathrm{~cm} / \mathrm{y}$ to $14 \mathrm{~cm} / \mathrm{y}$. The plots of the horizontal component versus the vertical component (Figure $4 \mathrm{~b}$ ) show that the displacement vectors are roughly parallel to the slope, highlighting the translationnal character of the slide. Piezometric measurements (not shown) performed over 2 years in a hole close to GPS point 44 indicate the water table at about $2 \mathrm{~m}$ deep, with seasonal variations of about $1 \mathrm{~m}$.

\section{Geophysical investigation}

Five methods (seismic noise measurement, electrical resistivity tomography, P-wave seismic refraction, S-wave seismic refraction and surface wave inversion) were used in the studied zone. The location of the different profiles is given in Figure $3 \mathrm{~b}$ and 3c.

\section{Seismic noise measurements}

Seismic noise measurements have been increasingly used during these last fifteen years in earthquake engineering for determining the geometry and shear wave velocity values of the soil layers overlying the bedrock (Bonnefoy, 2006; Wathelet, 2004). The single station method (also called the $\mathrm{H} / \mathrm{V}$ technique) consists in calculating the horizontal to vertical spectral ratio of the noise records and allows the resonance frequency of the soft layer to be determined (Nakamura, 1989). For a single homogeneous soft layer, this fundamental frequency is given by $f_{0}=V_{s} / 4 T$ where $V_{s}$ is the soft layer shear wave velocity and $T$ is the layer thickness. A description of the method is given by Bard (1998). In this study, measurements of ambient vibrations were made every $50 \mathrm{~m}$ along two profiles (HV1 and $\mathrm{HV} 2$, Figure $3 \mathrm{~b}$ ) using $5 \mathrm{~s}$ sensors. $\mathrm{H} / \mathrm{V}$ spectral curves for profile $\mathrm{HV} 1$ are presented in Figure $4 \mathrm{a}$ at two stations, as well as the $\mathrm{H} / \mathrm{V}$ ratios for all the 18 stations as a function of frequency and distance in a black and white scale. $\mathrm{H} / \mathrm{V}$ curves both exhibit a well defined and single peak at $2 \mathrm{~Hz}$ (station 3) and $0.6 \mathrm{~Hz}$ (station 15) with amplitude over 5. The H/V ratio map shows that the peak frequency regularly increases eastward, from about $0.5 \mathrm{~Hz}$ to $3.5 \mathrm{~Hz}$. Considering the relation $\mathrm{f}_{0}=\mathrm{V}_{\mathrm{s}} / 4 \mathrm{~T}$, the evolution of the resonance frequency values is in agreement with the decrease of the clay thickness from $200 \mathrm{~m}$ to the West to about $20 \mathrm{~m}$ to the East. 


\section{(a) $\mathbf{w}$}
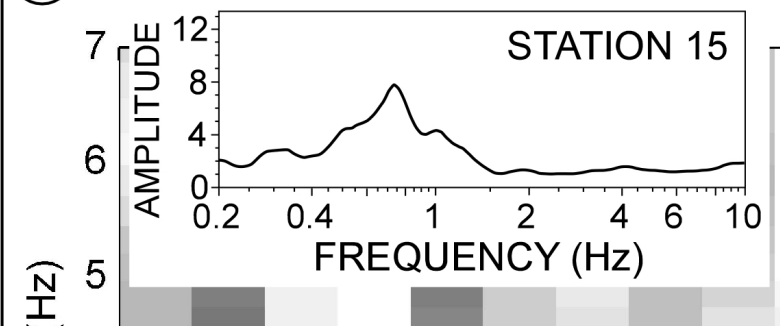

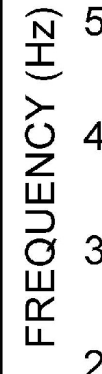

2

1
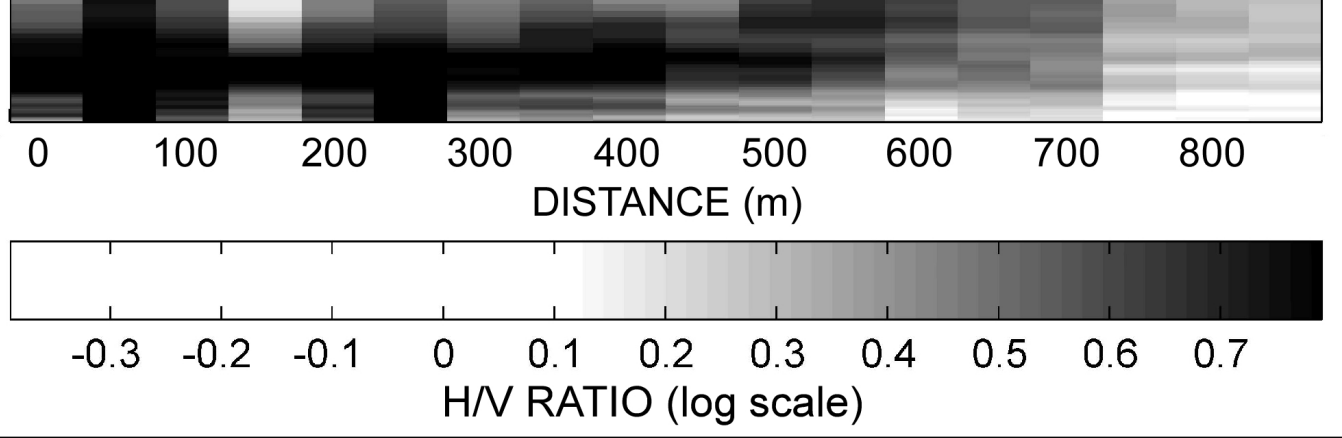

\section{(b)}

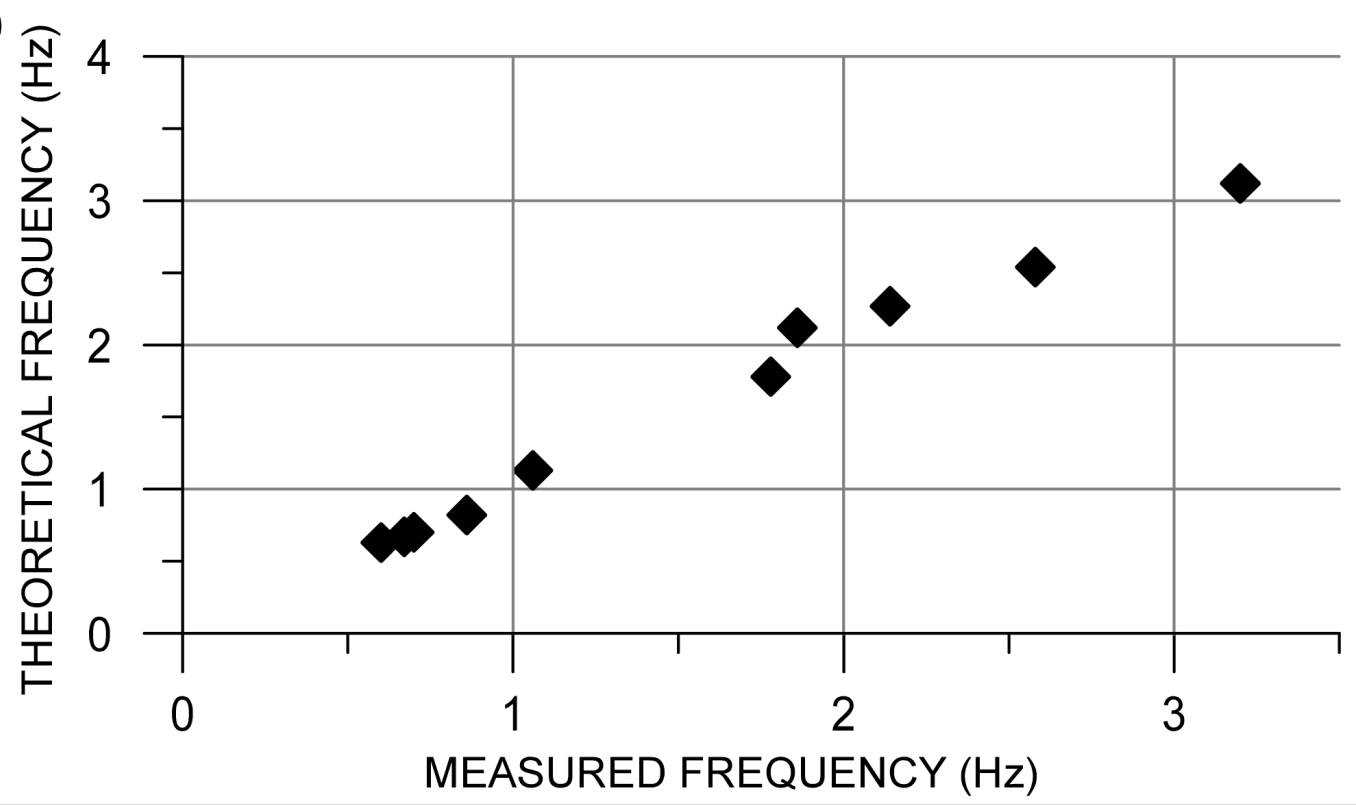

Figure 5: a) $H / V$ spectral ratio as a function of frequency and distance along profile HV1 (see Figure 5 for location). H/V curves are plotted for stations $03(750 \mathrm{~m})$ and $15(150 \mathrm{~m}) . \mathrm{b})$ Plot of the theoretical resonance frequency as a function of the measured one. Parameters used for theoretical frequency calculation are presented in table 1. 


\begin{tabular}{|l|l|l|l|}
\hline Geological unit & Vs $(\mathrm{m} / \mathrm{s})$ & Density & Quality factor $\left(=0.1^{*} \mathrm{Vs}\right)$ \\
\hline Moraines & 250 & 1.9 & 25 \\
\hline Disturbed clays & 300 & 2 & 30 \\
\hline Varved clays & 650 & 2 & 65 \\
\hline Alluvium & 1250 & 2 & 125 \\
\hline Carbonate bedrock & 2000 & 2 & 200 \\
\hline
\end{tabular}

Table 1: Dynamic characteristics considered within the layers for the computation of the resonance frequency. See text for details.

Using the method of Kennet (2002), the resonance frequency below each station was computed from the 1D geometry and the properties of the five layers (moraine, disturbed clay, clay, alluvium and bedrock). The considered dynamic characteristics (shear wave velocity Vs, density and quality factor Qs) of the layers are given in Table 1. Vs values were obtained from our study in the shallow layers (see below), from previous seismic refraction tests (Blanchet, 1988) and from the results of a cross-hole test performed in the same formations (Méneroud et al., 2005). Qs values were derived from Vs ones, using the relation Qs $=\mathrm{Vs} / 10$ proposed by Olsen et al. (2003). Theoretical and experimental values of the resonance frequency $\mathrm{f}_{0}$ are compared in Figure $5 \mathrm{~b}$ and show a very good agreement. Sensitivity tests have shown that the main factor controlling $\mathrm{f}_{0}$ is the total clay thickness, indicating that the $\mathrm{H} / \mathrm{V}$ method is a robust tool for mapping soft deposits as already observed by Delgado et al. (2000). On the contrary, no change in the $f_{0}$ value is found when passing the landslide top. The same results were obtained for profile HV2.

\section{Electrical Resistivity Tomography}

Electrical resistivity methods are based on measuring the electrical potentials between one electrode pair while transmitting a direct current between another electrode pair (Reynolds, 1997). In Electrical Resistivity Tomography (ERT), a large number of electrodes and combinations of electrode pairs are used, providing a 2D image of electrical resistivity. Three electrical profiles (labelled EP1 to EP3) were conducted on the site, using the Wenner configuration. Their location is given in Figure 3c. Profile EP1, striking EW, was performed downslope with 64 electrodes $5 \mathrm{~m}$ apart, while EP2 and EP3 were made perpendicular to the slope with 64 electrodes spaced by $2.5 \mathrm{~m}$. Electrical data were processed with the algorithm developed by Loke and Barker (1996) and the electrical images are shown in Figure 6. The three profiles were acquired in autumn just before the rainy period. All profiles show a more or less continuous shallow resistive layer (resistivity over $60 \mathrm{ohm} . \mathrm{m}$ ) of a few $\mathrm{m}$ thick corresponding to the colluvium made up of a mixing of moraines and clay, which is over the water table. Below the water table, resistivity values are usually lower (between 10 and 40 ohm.m) corresponding to the saturated varved clays. Resistive levels (over $60 \mathrm{ohm} . \mathrm{m}$ ) are detected at depth in the eastern part of the EP1 profile and at about $18 \mathrm{~m}$ depth below the EP2 profile. These resistive levels could correspond to the top (blocky clay) of the alluvial layers which were found at $14.5 \mathrm{~m}$ in borehole T2. The third electrical profile EP3, which crosses a highly deformed zone at its southern end, pointed out a relatively homogeneous conductive structure below the surficial resistive layer. Even if some weak lateral resistivity variations are observed in the clay deposits for all profiles, which are probably linked to water content changes, no systematic and clear relation was found between the electrical resistivity and the deformed zones. In such saturated, soft and conductive material, our interpretation is that gravitational deformation can not change significantly the resistivity values which are already low, contrary to what was observed in compact shale and marl where degradation allowed the water content to be increased (Caris and van Asch, 1991, Lapenna et al., 2005). 
Figure 6: Electrical profiles EP1 to EP3. a) Profile EP1 with 64 electrodes separated by $5 \mathrm{~m}$; final misfit value is $1.6 \%$ after 5 iterations. b) Profile EP2 with 64 electrodes separated by $2.5 \mathrm{~m}$; final misfit value is $2.4 \%$ after 5 iterations. c) Profile EP3 with 64 electrodes separated by $2.5 \mathrm{~m}$; final misfit value is $2.8 \%$ after 5 iterations.

\section{P-wave refraction tomography}

In this method the first arrivals in the seismic signals are inverted to get an image of the Pwave velocity distribution in the ground, assuming that the velocity increases with depth (Kearey et al., 2002). For this study, two 470m long profiles (SP4 and SP3, Figure 3) were conducted with 48 vertical geophones $(4.5 \mathrm{~Hz})$ spaced by $10 \mathrm{~m}$. The signals were generated by 9 and 14 explosive sources with a spacing of $80 \mathrm{~m}$ and $50 \mathrm{~m}$, respectively, including 1 to 2 offset shots at each end, depending on the available space. Three other $115 \mathrm{~m}$ long profiles (SP1A, SP1B and SP2) were also carried out with 24 vertical geophones $(4.5 \mathrm{~Hz})$ spaced by $5 \mathrm{~m}$. Figure $7 \mathrm{a}$ shows the seismograms recorded along profile SP4 for an offset shot at $-85 \mathrm{~m}$. One can easily distinguish the P-waves from the surface waves (Rayleigh waves). The first arrival times were picked for all shots and the time-distance graphs for three of them are plot in Figure $7 \mathrm{~b}$. Below a thin surficial layer with a low velocity (less than $500 \mathrm{~m} / \mathrm{s}$ ), the clay deposits appears to be characterized by a very constant velocity around $1900 \mathrm{~m} / \mathrm{s}$.

The first-arrival times were inverted by the simultaneous iterative reconstruction technique (SIRT; Dines and Lyttle, 1979), starting with a two-layer model derived from the classical interpretation of the graphs of Figure 7b. Seismic images for profiles SP4 and SP3 are given in Figures $7 \mathrm{c}$ and $7 \mathrm{~d}$, respectively. A misfit value lower than $1 \%$ was obtained in both cases after 3 iterations. Both profiles show a sharp vertical gradient in velocity, from a value lower than $1000 \mathrm{~m} / \mathrm{s}$ near the surface to $1600-1800 \mathrm{~m} / \mathrm{s}$ at less than $10 \mathrm{~m}$ depth. The first seismic layer corresponds to the moraine deposits and the unsaturated clay, while the second layer, whose velocity increases slightly with depth, is the saturated clay. Profile SP4 crosses the landslide limit (between $270 \mathrm{~m}$ and $300 \mathrm{~m}$ ) and no significant P-wave lateral velocity variation is visible in Figure 7c. Also, although the ground is much more deformed in the lower part of SP3, the seismic image of Figure 7D does not show any lateral change. Pwave velocity in this case seems to be mainly controlled by the water level and little affected by the gravitational deformation. Similar results were obtained along the shorter profiles SP1 and SP2. 


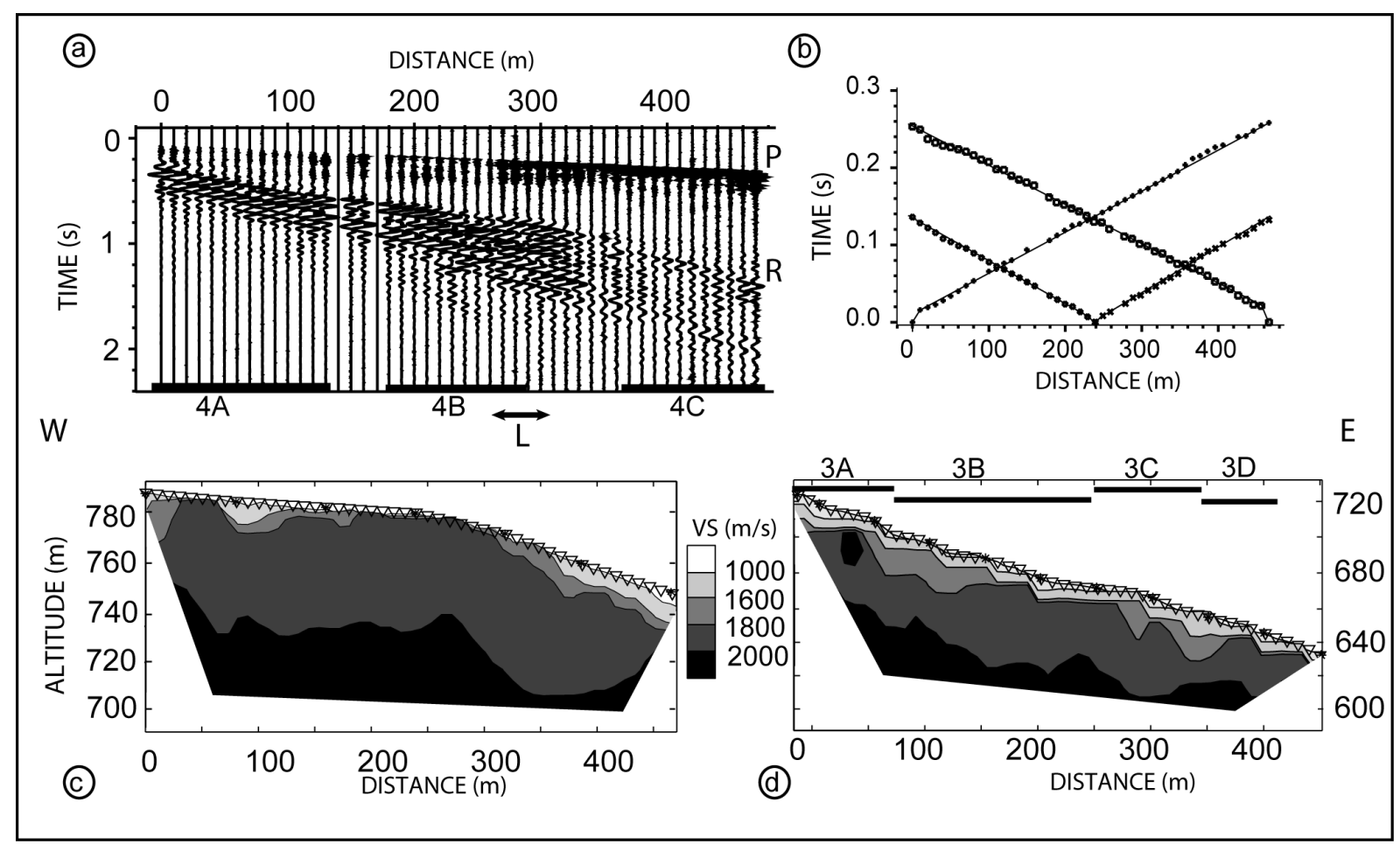

Figure 7: P-wave refraction study. a) Seismograms recorded along profile SP4 for an offset shot at $-85 \mathrm{~m}$. P: P-waves, R: Rayleigh waves. Bold bars labelled $4 \mathrm{~A}$ to $4 \mathrm{C}$ locate the groups of geophones used for the surface wave inversion, double arrow $L$ indicates the location of the landslide top . b) Travel-time versus distance graphs for the three shots at $0 \mathrm{~m}$, $250 \mathrm{~m}$ and $470 \mathrm{~m}$ along SP4. c) and d) P-wave velocity images along profiles SP4 and SP3, respectively. The initial model for the inversion is a $9 \mathrm{~m}$ thick layer $(\mathrm{Vp}=500$ and $650 \mathrm{~m} / \mathrm{s}$, respectively) over a half space $(\mathrm{Vp}=2500 \mathrm{~m} / \mathrm{s})$.

\section{S-wave velocity measurements}

Shear wave velocity (Vs) can be measured by various methods including active source techniques (borehole tests, SH refraction tests, surface wave inversion) and ambient vibration techniques (Jongmans, 1992; Socco and Jongmans, 2004). In this study we applied the SH seismic refraction method and the surface wave (SW) inversion for deriving Vs values along the cross-section $\mathrm{ZZ}$ '. An advantage of SW is that they are recorded together with P-wave refraction, if a sufficient time length recording is considered during the acquisition. However, inversion of surface waves is theoretically limited to 1D velocity structures, although some smooth variations can be considered using the MASW technique (Park et al., 1999). In the context of landslides, significant lateral Vs variations are expected in the highly deformed zones and the inversion of surface waves might be unusable. On the contrary, the SH refraction technique yields Vs 2D images, using the same algorithm (SIRT) as for P-waves. Both methods suffer the non uniqueness problem (Wathelet et al., 2004; Ivanov et al., 2006) and have to be calibrated. In this study, we imposed the same solutions for the two data sets in the overlapping parts of the surveys. Dispersion curves for the fundamental mode of Rayleigh waves were computed using the $\mathrm{f}-\mathrm{k}$ method and inverted applying the Neighbourhood Algorithm (Socco and Strobbia, 2004; Wathelet et al., 2004). 

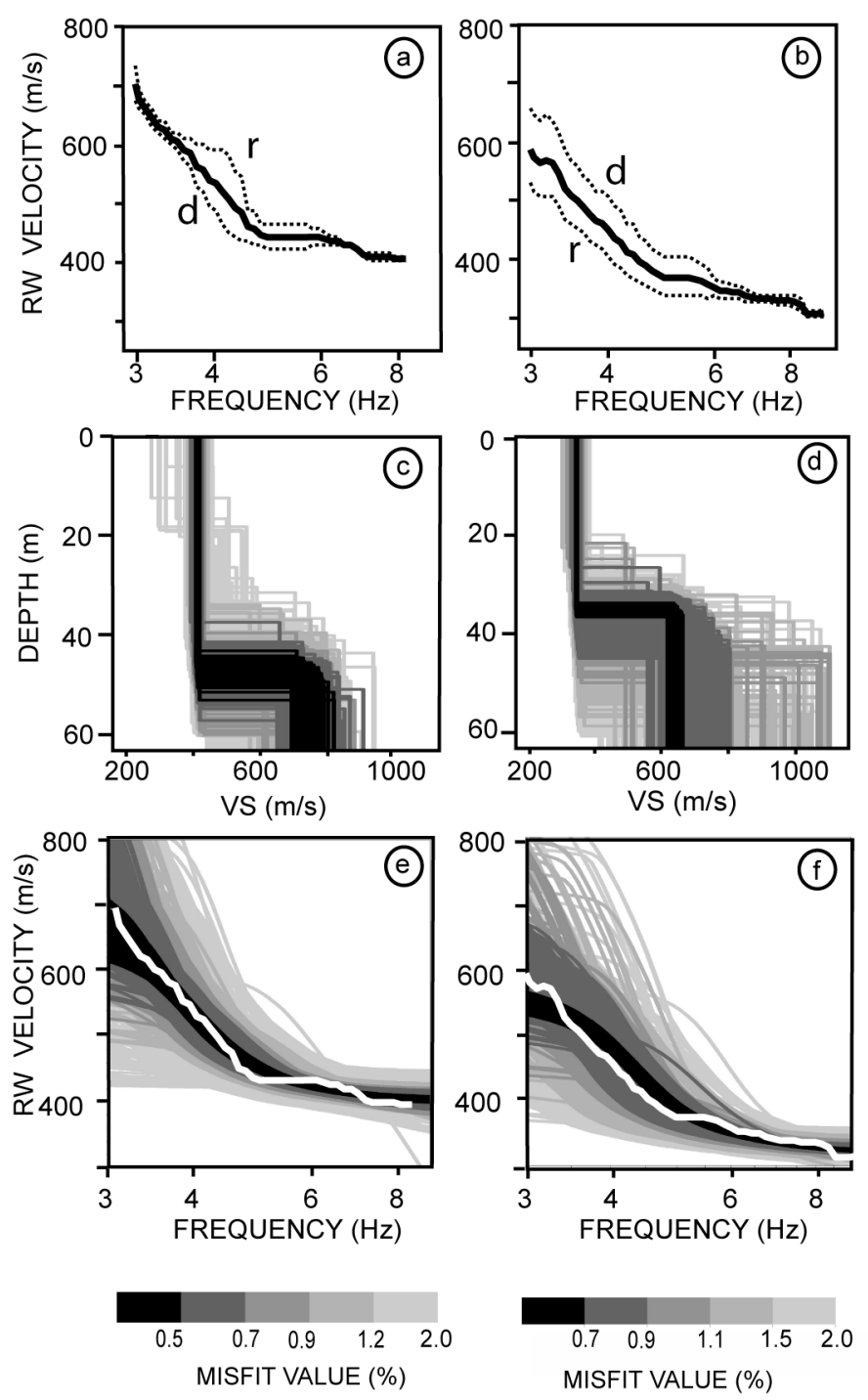

Figure 8. Surface wave inversion (Rayleigh waves, fundamental mode) performed on 2 groups of seismograms along profile SP4. Left column: group P4A. Right column: group P4B. a) and b) Dispersion curves for direct (d) and reverse ( $r$ ) shots with offset. The black line corresponds to their average. c) and d) Vs profiles resulting from the inversion of these dispersion curves. e) and f) Corresponding calculated dispersion curves with the average experimental data. Models and dispersion curves are plotted with a misfit black and white scale.

The two long seismic profiles SP3 and SP4 were used to study the Rayleigh wave propagation along the sliding mass. Groups of geophones that roughly correspond to homogenous 1D media were selected from the seismogram examination and the P-wave images: 3 groups along SP4 (A: 1-15, B: 19-30, C: 38-48; Figure 7a) and 4 groups along SP3 (A: 5-14, B: 14-20, C: 21-40, D: 40-48, Figure 7d). The results of the SW inversion for the two groups SP4A and SP4C are presented in Figure 8. Profile SP4 was performed across the landslide limit which is located between $270 \mathrm{~m}$ and $300 \mathrm{~m}$ (Figure 7a). Dispersion curves were computed for the two offset shots (direct and reverse) in order to test the 1D hypothesis and the average of the two curves was computed (Figure $8 \mathrm{a}$ and $\mathrm{b}$ ). Within the landslide (Figure 8b), the Rayleigh wave curve exhibits lower values than in the undisturbed area (Figure 8a), over the whole frequency range. Dispersion curves are inverted assuming a two 
layer model (Figure 8c and d). Out of the landslide, Vs velocity in the upper 45-50 m thick layer is about $400 \mathrm{~m} / \mathrm{s}$ and decreases slightly to $350 \mathrm{~m} / \mathrm{s}$ within the slide. Also, the velocity in the second layer decreases from $700-800 \mathrm{~m} / \mathrm{s}$ to $650 \mathrm{~m} / \mathrm{s}$.

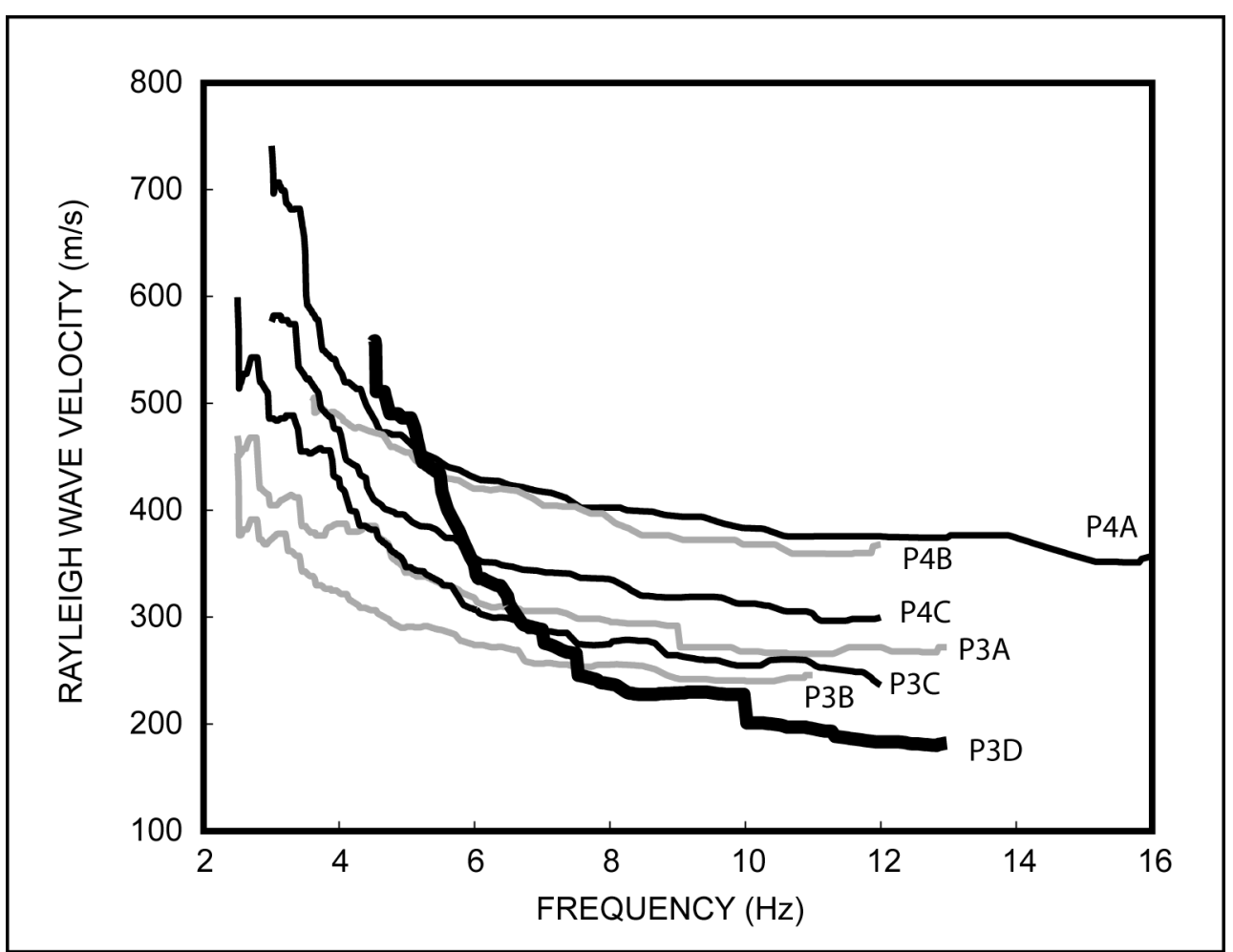

Figure 9. Comparison of the dispersion curves calculated along the landslide. P4A to C correspond to geophones 1-15, 19-30 and 38-48, respectively. P3A to D correspond to geophones 40-48, 21-40, 14-20 and 5-14, respectively.

Figure 9 shows the phase velocity dispersion curves computed for the seven groups of geophones (profiles SP3 and SP4), with a common frequency range between 3 and $13 \mathrm{~Hz}$. The striking feature is that, in the high frequency range (over $8 \mathrm{~Hz}$ ), Rayleigh wave velocities regularly decrease from the top (P4A) to the bottom of the hill (P3D), with the exception of P3C. Phase velocity values at $10 \mathrm{~Hz}$ are divided by 2 , from $400 \mathrm{~m} / \mathrm{s}$ out of the landslide to $200 \mathrm{~m} / \mathrm{s}$ in the most deformed zones. The lower frequencies do not show a similar phase velocity decrease along the profile because they sample in the bottom part the compact underlying alluvial deposits characterized by much higher velocities (see, for instance the curve P3D). The seven dispersion curves were inverted using the Neighbourhood Algorithm (Wathelet et al., 2004), with two different parameterisations: a simple two layer model, and a two layer model with a linear increase within the top layer. On the basis of the combined analysis together with $\mathrm{SH}$ refraction, the simple two layer model was selected and the results will be discussed in the following section.

Regarding the $\mathrm{SH}$ wave refraction technique, three $115 \mathrm{~m}$ long profiles were performed at the same place as the short P-waves profiles (SP1A, SP1B, SP2). SH waves were generated by hitting a weighted plank oriented perpendicular to the profile direction and recorded by horizontal $14 \mathrm{~Hz}$ geophones. Seismograms were recorded for $9 \mathrm{SH}$ sources regularly spaced along each profile. Figure 10a shows the seismograms recorded for an end shot along profile SP1A, while the travel-time versus distance graphs are presented in Figure 10b for the two extreme and the middle shots. Compared to P-waves, $\mathrm{SH}$ arrival time graphs exhibit a more complex shape, with either a 3 layer case (as shown by the two extreme shots in Fig. 10b), or a continuous increase of the velocity. Apparent Vs values are ranging from about $220 \mathrm{~m} / \mathrm{s}$ to 
$730 \mathrm{~m} / \mathrm{s}$. All picked SH wave times were inverted using the SIRT technique, starting with different initial models. Figures 10c and 10d show the models obtained for the two profiles SP1A and SP1B, that explain both the SH wave and the surface wave data at the same place. SH-wave images exhibit a thick low-velocity layer (Vs about $250 \mathrm{~m} / \mathrm{s}$ ) overlying a more compact layer (Vs $>600 \mathrm{~m} / \mathrm{s}$ ) found at a depth varying between $20 \mathrm{~m}$ from the top to $12 \mathrm{~m}$ at the bottom of the profile. This range is consistent with the depth of the slip surface $(13 \mathrm{~m})$ detected in T2 (Figure 4c). Moreover, the Vs image of profile SP1B shows a lateral velocity decay (from $250 \mathrm{~m} / \mathrm{s}$ to $200 \mathrm{~m} / \mathrm{s}$ ) in the top layer towards the bottom of the profile, which coincides with the slide velocity increase. This point will be discussed in the next section.

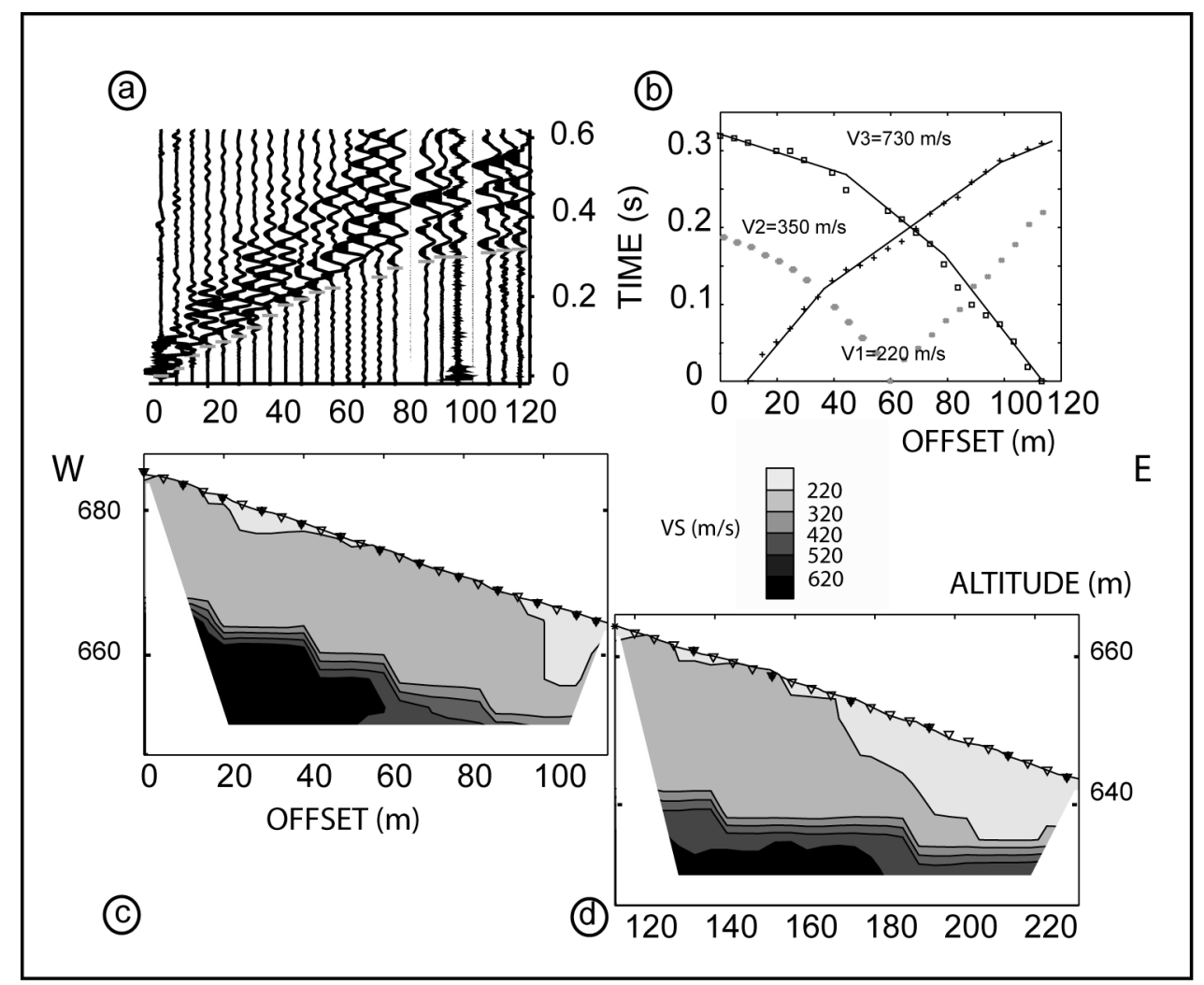

Figure 10: SH wave refraction study. a) Seismograms recorded along profile SP1A for a shot at $0 \mathrm{~m}$. b) Traveltime-distance graphs for the 3 shots at $15 \mathrm{~m}, 60 \mathrm{~m}$ and $115 \mathrm{~m}$ along profileP1A. c) and d) SH-wave velocity images for profiles $P 1 A$ and $P 1 B$, respectively. Misfit values are lower than $2.5 \%$. The initial model is a $20 \mathrm{~m}$ thick layer $(V s=250 \mathrm{~m} / \mathrm{s})$ over a half space $\left(V_{s}=800 \mathrm{~m} / \mathrm{s}\right)$.

\section{Discussion and conclusion}

Vs measurements for all profiles are summarized in Figure 11, along the cross-section ZZ'. For comparison, Vs values measured on the plateau at $800 \mathrm{~m}$ from the slide top are also plotted, along with the value of Vs obtained at $25 \mathrm{~m}$ depth by a cross-hole test for a bridge investigation (Méneroud et al., 1995). In Figure $11 \mathrm{~b}$ are plotted Vs values (measured by the two methods) versus distance at a depth of $5 \mathrm{~m}$, together with the slide velocity measurements. The striking feature is the regular decay of Vs values along the section, from $500 \mathrm{~m} / \mathrm{s}$ far from the slide to $200 \mathrm{~m} / \mathrm{s}$ at the slide toe. Within the slide, the Vs variation is opposite to the slide velocity curve, suggesting that the gravitational deformation strongly affects the shear wave velocity within the clay, contrary to what was observed for P-wave velocity and electrical resistivity. Vs values averaged at $25 \mathrm{~m}$ depth are shown in Figure 11c. 
At that depth, Vs values are higher $(500-600 \mathrm{~m} / \mathrm{s})$ at the slide toe than at and over the head scarp $(400 \mathrm{~m} / \mathrm{s})$, resulting from the presence of the stiff alluvial layers. Two independent measurements made far from the slide at the same depth show Vs values higher (600-650 $\mathrm{m} / \mathrm{s}$ ) than the ones measured near the head scarp. These results, along with the values measured at $5 \mathrm{~m}$ depth, suggest that the slide has already degraded the clay mass at the rear, over a distance of a few hundreds meters.

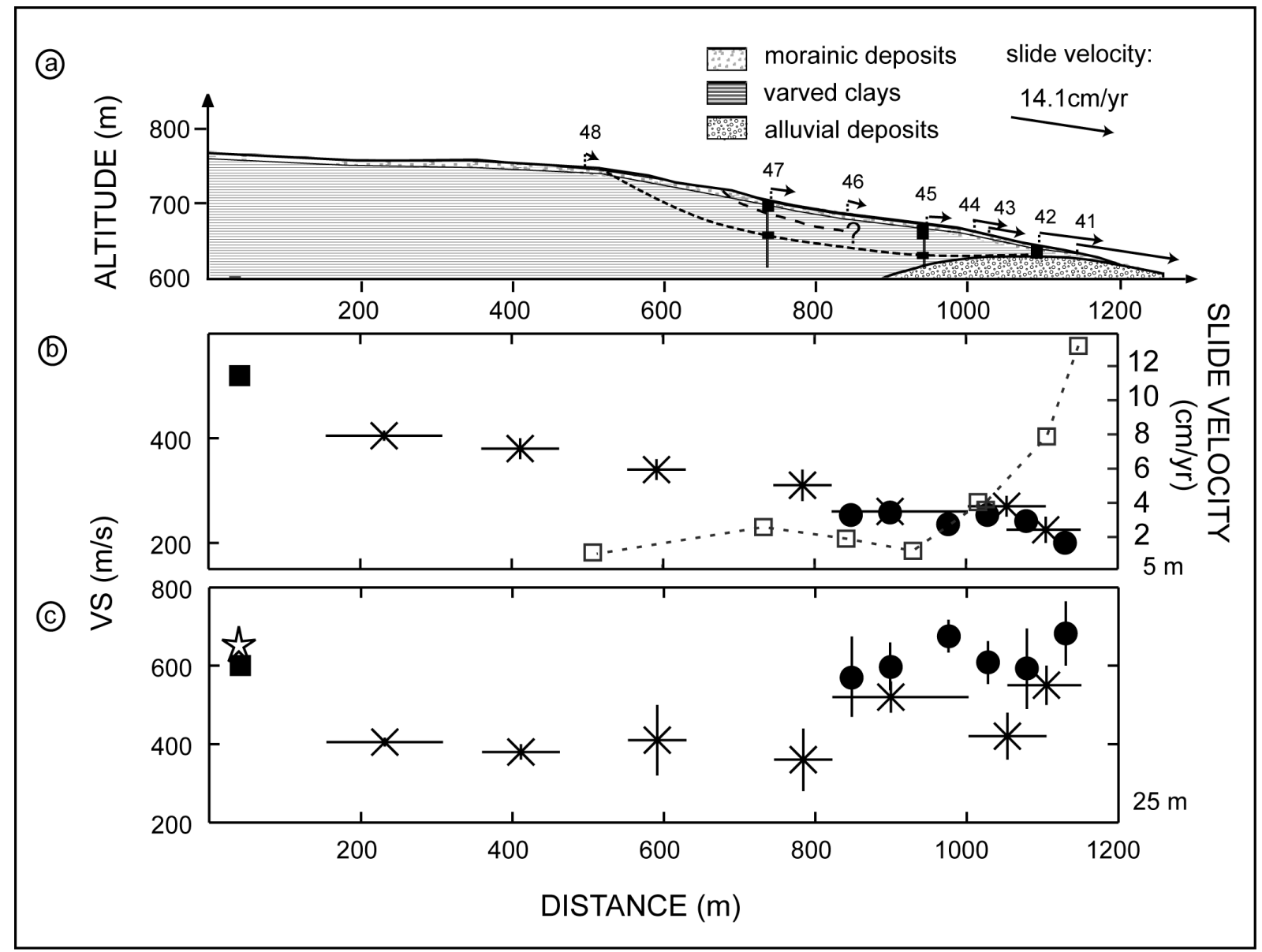

Figure 11: a) Geotechnical cross-section ZZ' with the arrows of the slide velocity. b) and c) $V s$ values at $5 \mathrm{~m}$ and $25 \mathrm{~m}$ depth as a function of distance with vertical error bars. Crosses: $V s$ values deduced from $S W$ inversion, with horizontal bars indicating the distance range. Dots: Vs values from SH wave refraction. Square: Vs values measured at $800 \mathrm{~m}$ from the slide limit on the plateau. Star: Vs value measured in a remote cross-hole test. In Figure $b$ are plotted the slide velocity values.

Vs values measured on the Avignonet site (from $200 \mathrm{~m} / \mathrm{s}$ to $600 \mathrm{~m} / \mathrm{s}$ ) are in a range similar to the one obtained by Mondol et al. (2007) in saturated marine clay for vertical effective stresses between 5 and $40 \mathrm{MPa}$, corresponding to burial depths from a few hundreds of meters to a few kilometres. This difference of depths is probably due to the overconsolidation of the laminated clay resulting from the action of the glacier, as well as to the silty component of the material. This comparison nevertheless illustrates the significant effect of the slide on the Vs values, with a division by a factor of 2.5 between the zones unaffected and strongly deformed by the landslide. This decay probably results from the decompaction and intensive cracking at different scales of the laminated clay. 
All these results suggest that Vs mapping could provide valuable information on the deformation state of the clay material at depth and that the Vs evolution with time could be used as an indicator for characterizing the landslide activity. If the slide evolves into a flow, Vs should even tend to zero in the zones behaving as a fluid. The methods as well as the corresponding layouts and instruments used in this study for determining Vs are limited to a penetration depth between $25 \mathrm{~m}$ and $40 \mathrm{~m}$. In the future, an effort should be made to develop Vs measurement techniques which are repetitive and reliable at greater depth. The recent application of cross-correlation techniques on the seismic noise recorded by permanent seismic stations (Larose et al., 2006) offers Vs imaging possibilities which should be tested on landslides in the future.

\section{Acknowledgments}

This work was financially supported by regional and national funds coming from the Conseil Général de l'Isère, the region Rhône-Alpes and the Cluster VOR (Vulnérabilité des Ouvrages aux Risques). The authors thank all the people who participated to the field investigation.

\section{References}

Antoine, P., Giraud, A. and Monjuvent, G., 1981, Les argiles litées du Trièves (Isère); conditions de gisement et exemples de propriétés géotechniques: Bulletin de la société géologique de France, 23, 117-127.

Archie, G. E., 1942, The electrical resistivity log as an aid in determining some reservoir characteristics: PetroleumTechnology, 1, 55-62.

Bard, P.-Y., 1998, Microtremor measurements: a tool for site effect estimation ? Proceeding of the Second International Symposium on the Effects of Surface Geology on Seismic Motion, Yokohama, Japan, 3, 1251-1279.

Blanchet F., 1988, Etude géomécanique de glissements de terrain dans les argiles glaciolacustres de la vallée du Drac, Ph. D. thesis, Grenoble university, $157 \mathrm{p}$.

Bogoslovsky, V.A., and Ogilvy, A.A. ,1977, Geophysical methods for the investigation of landslides: Geophysics, 42, 562-571.

Bonnefoy-Claudet, S., Cornou, C., Bard, P.-Y., Cotton, F., Moczo, P., Kristek, J. and Fäh, D., 2006, H/V ratio: a tool for site effects evaluation. Results from 1-D noise simulation: Geophysical Journal International, 167, 827-837.

Caris, J.P.T. and T.W.J. van Asch, 1991, Geophysical, geotechnical and hydrological investigations of a small landslide in the French Alps: Engineering Geology, 31(3-4), 249276.

Delgado, J., Lopez Casado, C., Estevez, A., Giner, J., Cuenca, A., and Molina, S. 2000. Mapping soft soils in the Segura River valley (SE Spain): a case of study of microtremors as an exploration tool: Journal of Applied Geophysics, 45, 19-32.

Dines, K., and Lyttle, J., 1979. Computerized geophysical tomography: Proceedings of the Institute of Electrical and Electronics Engineers, 67, 1065-1073.

Gallipoli, M., Lapenna, V., Lorenzo, P., Mucciarelli, M., Perrone, A., Piscitelli, S., and Sdao, F., 2000: Comparison of geological and geophysical prospecting techniques in the study of a landslide in southern Italy: European Journal of Environmental and Engineering Geophysics, 4, 117-128. 
Giraud, A., Antoine, P., van Asch, T.W.J., and Nieyuwenhuis, J.D., 1991, Geotechnical problems caused by glaciolacustrine clays in the French Alps: Engineering Geology 31, 185-195.

Guillier, B., Cornou, C., Kristek, J., Bonnefoy-Claudet, S., Bard, P.Y., Faeh, D., and Moczo, P., 2006, Simulation of seismic ambient vibrations: does the $\mathrm{H} / \mathrm{V}$ provide quantitative information in 2D-3D structure: ESG2006, Grenoble.

Grandjean, G., Pennetier, C., Bitri, A., Méric, O., and Malet, J.P., 2006, Caractérisation de la structure interne et de l'état hydrique de glissements argilo-marneux par tomographie géophysique: l'exemple du glissement-coulée de Super-Sauze: Comptes Rendus Geosciences, 338(9), 587-595

Ivanov, I., Miller, R.D., Xia, J., Steeples, D., and Park, C.B., 2006, Joint analysis of refractions with surface waves: An inverse solution to the refraction-traveltime problem, Geophysics, 71(6), R131-R138.

Jongmans, D., 1992, The application of seismic methods for dynamic characterization of soils in earthquake engineering: Bulletin of the International Association of Engineering Geology, 46, 63-69.

Jongmans, D., and Garambois, S., 2007, Geophysical investigation of landslides: A review: Bulletin Société Géologique de France, 178, 2.

Kearey, P., Brooks, M., and Hill, I., 2000, An introduction to geophysical exploration, Blackwell Science, $264 \mathrm{p}$.

Kennett B.L.N., 2002, The Seismic Wavefield: Vol. 1 : Introduction and Theoretical Development, Cambridge, 368 p.

Lapenna, V., Lorenzo, P., Perrone, A., Piscitelli, S., Rizzo, E., and Sdao F., 2005, 2D electrical resistivity imaging of some complex landslides in Lucanian Apennine chain, southern Italy: Geophysics, 70, B11-B18.

Larose, E., Margerin, L., Derode, A., van Tiggelen, B., Campillo, M., Shapiro, N., Paul, A., Stehly, L., and Tanter, M., 2006, Correlation of random wave fields: an interdisciplinary review: Geophysics, 71, SI11-SI21.

Leucci, G., and De Giorgi, L., 2006, Experimental studies on the effects of fracture on the P and S wave velocity propagation in sedimentary rock ("calcarenite del Salento"): Engineering Geology, 84, 130-142.

Lorier, L., and Desvarreux, P., 2004, Glissement du Mas d'Avignonet, commune d'Avignonet: Proceedings of the workshop Ryskhydrogeo, Program Interreg III, La Mure (France), 8p.

Loke, M.H., and Barker, R.D., 1996, Rapid least-squares inversion of apparent resistivity pseudosections using a quasi-Newton method: Geophysical Prospecting, 44, 131-152.

McCann, D.M., and Forster, A., 1990, Reconnaissance geophysical methods in landslide investigations: Engineering Geology, 29, 59-78.

Méric, O., Garambois, S., Cadet, H., Malet, J-P., Guéguen, P., and Jongmans, D., 2007, Seismic noise based methods for soil landslide characterization, Bulletin Société Géologique de France, 178, n².

Mavko, G., Mukerji, T., and Dvorkin, J., 2003, The Rock Physics Handbook, Tools for Seismic Analysis of Porous Media, Cambridge, 339 p.

Méneroud J.-P., Duval, A.-M. , Vidal, S., Fréchet, J., Gamond, J.-F., Beck, C., Tardy, M., Bard, P.-Y., Barnichon, E., and Gaboriaud, J.-M., 1995, A51 Grenoble - Sisteron, Franchissement de l'Ebron, Etude de l'aléa sismique local: internal report CETE Méditerranée, ${ }^{\circ}$ 93/95666/74, 176 p.

Mondol, N.H., Bjorlykke, K., Jahren, J., and Hoeg, K., 2007, Experimental mechanical compaction of clay mineral aggregates - changes in physical properties of mudstones during burial: Marine and Petroleum Geology, in press. 
Moulin, C., and Chapeau, C., 2004, Le glissement de la Salle en Beaumont (Isère), Proceedings of the workshop Ryskhydrogeo, Program Interreg III, La Mure (France), 9 p.

Moulin, C., and Robert, Y., 2004, Le glissement de l'Harmalière sur la commune de Sinard: Proceedings of the workshop Ryskhydrogeo, Program Interreg III, La Mure (France), 11 p.

Monjuvent, G., 1973, La transfluence Durance-Isère. Essais de synthèse du Quaternaire du bassin du Drac: Géologie Alpine, 49, 57-118.

Nakamura, Y. ,1989, A method for dynamic characteristics estimation of subsurface using microtremor on groung surface: QR of RTRI, 30, 25-33.

Olsen, K.B., Day, S.M., and Bradley, C. R., 2003, Estimation of Q for long-period ( $>2$ s) waves in the Los Angeles basin: Bull. Seismol. Soc. Am., 93, 627-638.

Park, C.B., Miller, R.D., and Xia, J., 1999, Multi-channel analysis of surface waves: Geophysics, 64(3), 800-808.

Picarelli, L., 2000, Mechanisms and rates of slope movements in fine grained soils: Int Conf Geotech Geol Eng GeoEng 2000, 1, 1618-1670.

Picarelli, L., Urciuoli, G., and Russo, C., 2004, The role of groundwater regime on behaviour of clayey slopes: Canadian Geotechnical Journal, 41, 467-484.

Reynolds, 1997, An introduction to applied and environmental geophysics, Wiley, 796p.

Schmutz, M., Albouy, Y., Guerin, R., Maquaire, O., Vassal, J., Schott, J.J., and Descloitres M., 2000, Joint inversion applied to the Super Sauze earthflow (France): Surveys in Geophysics, 21, 371-390.

Socco, L.V., and Jongmans, D., 2004, Special issue on Seismic Surface Waves: Near Surface Geophysics, 2, 163-258.

Socco, L.V., and Strobbia, C., 2004, Surface-wave method for near-surface characterization: a tutorial: Near Surface Geophysics, 2, 165-185.

Van Asch, Th.W.J, Hendriks, M.R., Hessel, R. and Rappange, F.E., 1996, Hydrological triggering conditions of landslides in varved clays in French Alps: Engineering Geology, 42, 239-251.

Wathelet, M., Jongmans, D., and Ohrnberger, M., 2004, Surface wave inversion using a direct search algorithm and its application to ambient vibration measurements: Near surface geophysics, 2, 211-221.

Willye, M.R.J., Gregory, A.R., and Gardner, L.W., 1956, Elastic wave velocities in heterogeneous and porous media: Geophysics, 21, 41-70. 